\begin{tabular}{l|c|c}
\hline ISSN: 0001-5113 & ACTA ADRIAT., & ORIGINAL SCIENTIFIC PAPER \\
AADRAY & 58(1): 125 - 136, 2017 & \\
\hline
\end{tabular}

\title{
Diet composition and overlap for 43 fishes in the North Aegean Sea, Greece
}

\author{
Paraskevi K. KARACHLE
}

\begin{abstract}
Institute of Marine Biological Resources and Inland Waters, Hellenic Centre for Marine Research, 46.7 km Athens Sounio ave., P.O. Box 712, 19013 Anavyssos Attiki, Greece
\end{abstract}

Corresponding author, e-mail: pkarachle@hcmr.gr

This study presents the diet composition of 43 of some of the most abundant fish species from the North Aegean Sea, Greece. According to the diet analysis and fractional trophic level previously reported in the literature, 20 of the studied species were omnivores with a preference for animals and the other half were carnivores (15 with preference for fish and Cephalopoda, and seven with preference for fish and Decapoda), whereas Parablennius gattorugine was the only recorded omnivore with a preference for plant material. Finally, according to the results of Schoener's index, diet overlap between species was recorded in a small number of cases (33 out of the 903 pairs examined). Yet, competition among diet-overlapping species may be minimised by either morphological differentiations and/or habitat segregation.

Key words: feeding habits, diet overlap, Schoener's index, Aegean Sea, East Mediterranean

\section{INTRODUCTION}

Nowadays, it is widely accepted that knowledge of the feeding ecology of both commercial and non-commercial species is fundamental for understanding intra- and inter- species interactions (e.g. HARMELIN-VIVIEN et al., 1989; PAULY, 2000; NIKOLIOUDAKIS et al., 2011; KARACHLE \& STERGIOU, 2014), trophodynamics, and food web structure and modeling (e.g. TSAGARAKIS et al., 2010; NIKOLIOUDAKIS et al., 2012, 2014), as well as for a multispecies approach to fishery management and the establishment of conservation and management plans (e.g. STERGIOU \& KARPOUZI (2002) and references therein). In the Mediterranean Sea, studies on fish feeding habits exit for 204 species (KARACHLE \& STERGIOU, 2017), a rather low number given that the ichthyofauna of the
Mediterranean comprises 767 species (FROESE \& PAULY, 2015).

The North Aegean Sea is one of the most important fishing grounds of the Hellenic Seas, contributing more than $50 \%$ of the overall catches both in the Aegean Sea and all Greek Seas combined (i.e. Aegean, Ionian, and NW Levantine) (STERGIOU et al., 1997; PAPACONSTANTINOU, 2005). The area is the most productive one (in terms of phytoplankton and zooplankton abundance) compared to other areas of the Hellenic Seas, and especially its N-NW part, due to nutrient influx, from four major rivers, in Thermaikos Gulf (e.g. STERGIOU et al., 1997; PAGOU, 2005; GOTSIS-SKRETAS \& IGNATIADES, 2007) and high urban and industrial development (e.g. MONCHEVA et al., 2001; PAGOU, 2005).

This study presents the diet composition of 43 species from the N-NW Aegean Sea, for 
many of which such information from the entire Mediterranean Sea and its eastern part, in particular, is poor; moreover, competition among these species for the same food resources has been examined. These species occupy different habitats in the general area (four benthopelagic species, seven reef-associated, 10 pelagic, and 22 demersal habitat types, according to FROESE \& PAULY (2015), Table 1), whereas both commercially important and discarded fish species were examined (24 and 19 species respectively). The aim of this study is to provide high-quality data on diet composition, which will be useful for the development of ecological models and thus future management of fisheries resources in this area that is important for the Hellenic fisheries.

\section{MATERIAL AND METHODS}

Samplings were conducted in the N-NW Aegean Sea area (Fig. 1), from June 2001 to January 2006, using commercial fishing vessels (i.e. bottom trawlers, purse-seiners, and gillnetters) operating mainly at depths $>50 \mathrm{~m}$; the objective was to collect the most abundant and/ or data deficient, with respect to diet composition, species. Overall, 60 samples were obtained ( 25 from trawlers, 14 from purse-seiners, and 21 from gillnetters), during all seasons (18 samples in spring, 14 in summer, 14 in autumn, and 14 in winter). A detailed account of the samplings, specimen collection and handling is given in KARACHLE \& STERGIOU (2008). All individuals were measured for total length ( $\mathrm{TL} \pm 1 \mathrm{~mm}$ ). Stomachs were removed and the contents were identified to the lowest possible taxon. For stomachless species (i.e. Coris julis, Belone belone, Labrus viridis, Lesueurigobius suerii, Symphodus tinca and Xyrichtys novacula), the anterior half of the digestive tract was used for diet analysis (BELL \& HARMELIN-VIVIEN, 1983). Each taxonomic group was weighed separately and the proportion of its contribution to the overall diet of the species was estimated (HYSLOP, 1980). The number of individuals examined per species is given in Table 1 (and Table S1, supplementary online material, along with the detailed description of their stomach contents, presented for the first time). The adequacy of sample size for the description of the feeding habits of any given species had been evaluated previously by KARACHLE \& STERGIOU (2008) who used two different methods (as described by LINK \& ALMEIDA (2000) and MORATO et al. (2003)). Both these methods are based on the assumption that a sample size is sufficient if the diet-related curve reaches an asymptote. An asymptote would imply that very few or no new prey items would be found in the stomach contents if additional samples were to be examined (LINK \& ALMEIDA, 2000). For the majority of species (i.e. 26 out of 43 species), the sample size was adequate for diet description (KARACHLE $\&$ STERGIOU, 2008) (Table 1). For 10 out of the remaining 17 species, that sample size, according to the asymptote method, could not support a detailed description of feeding habits, previous information on diet composition is lacking from the Eastern Mediterranean, constituting such data of high importance.

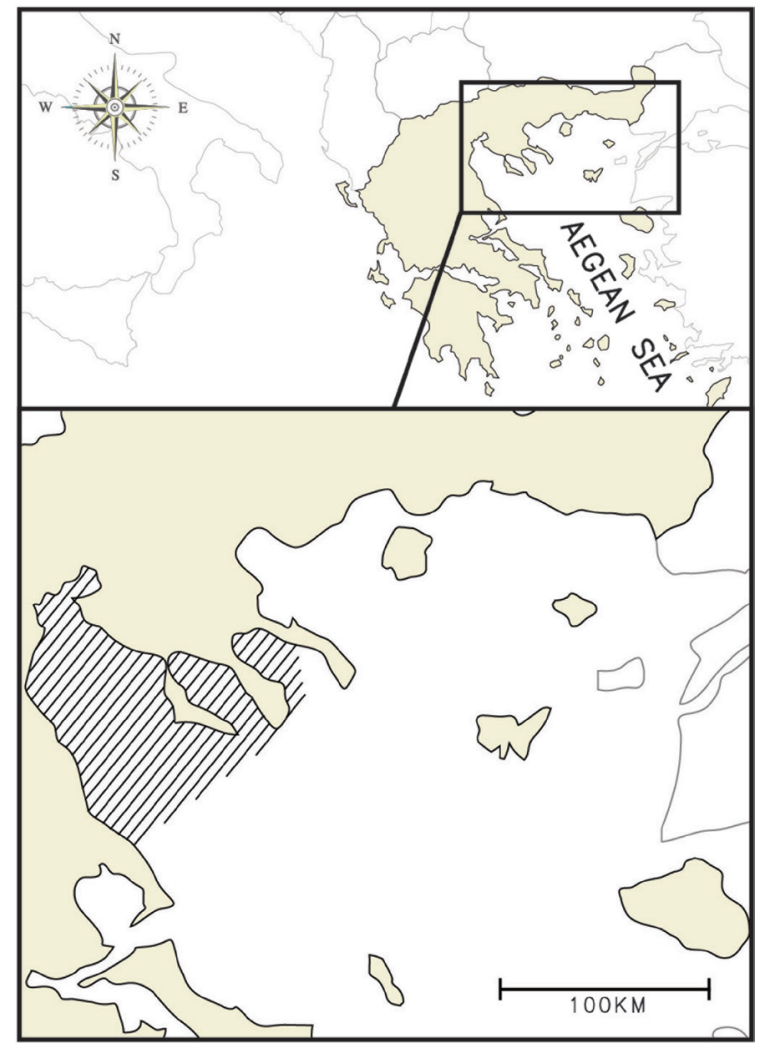

Fig. 1. Map of the sampling area (shaded) in the North Aegean Sea, Greece 
In order to assess the functional trophic group (following STERGIOU \& KARPOUZI (2002)) of each species, the fractional trophic level (TROPH), which was estimated using the quantitative routine of TrophLab (PAULY et al., 2000) and is given in KARACHLE \& STERGIOU (2008), was used. Classification to a functional trophic group (STERGIOU \& KARPOUZI, 2002) is as follows: a) pure herbivores $(2.0<\mathrm{TROPH}<2.1)$ $(\mathrm{H})$; b) omnivores with a preference for plants $(2.1<\mathrm{TROPH}<2.9)(\mathrm{OV})$; c) omnivores with a preference for animals $(2.9<\mathrm{TROPH}<3.7)$ $(\mathrm{OA})$; d) carnivores with a preference for Decapoda/fish $(3.7<$ TROPH $<4.0)(\mathrm{CD})$; and e) carnivores with a preference for fish/Cephalopoda $(4.0<\mathrm{TROPH}<4.5)(\mathrm{CC})$.

Finally, examination of the diet overlap between fish species pairs was performed using Schoener's index S (SCHOENER, 1970):

$$
S=1-0.5 \sum_{i=1}^{n}\left|P_{\mathrm{xi}}-P_{\mathrm{yi}}\right|
$$

where $\mathrm{P}_{\mathrm{xi}}$ and $\mathrm{P}_{\mathrm{yi}}$ are the proportions - in wet weight - of prey item ' $i$ ' found in the stomachs of predators $\mathrm{x}$ and $\mathrm{y}$. The values that $\mathrm{S}$ can take for any pair of species examined can range from 0 , for species that use completely different food resources, to 1 , when the food resources are used in the same proportions. In general, values higher than 0.6 indicate diet overlap and could be considered as significant (ZARET \& RAND, 1971; WALLACE, 1981; WALLACE \& RAMSEY, 1983).

All the above information was collected and analyzed according to the recommendations of STERGIOU \& KARPOUZI (2002) for an integrated examination of feeding habits.

\section{RESULTS}

A total of 43 species (3414 individuals) was examined (Table 1). Sample size ranged from one (for Labrus viridis and Trigloporus lastoviza) to 627 (Trachurus mediterraneus) individuals (mean \pm standard error $(\mathrm{SE})=79.40$ \pm 2.64 ) (Table 1; Table S1, supplementary online material).

The $\%$ contribution of the diet composition of the 43 species is given in Table S1. Of the 43 species examined, five species (namely
Alosa fallax, Caranx rhonchus, Lophius piscatorius, Pomatomus saltatrix and Sphyraena sphyraena) fed exclusively on fish, four (namely Eutrigla gurnardus, Lepidotrigla cavillone, T. lastoviza and Sciaena umbra) preyed exclusively on Crustacea, whereas L. viridis fed exclusively on Mollusca (Table 1; Table S1). With respect to the species for which no information about their feeding habits in the Mediterranean existed, Anthias anthias, Apogon imberbis and Lesueurigobius suerii fed on Crustacea (with Natantia being the most abundant food item in their diets), the diet of Blennius ocellaris comprising mainly of Polychaeta, Brachyura and to a lesser extent Gastropoda, whereas Merlangius merlangus, Scomber scombrus and S. sphyraena preyed mainly on fish (Table 1; Table S1). Based on their fractional trophic levels, nearly half of the species (20 species; $46.5 \%$ of the total number of species) were characterized as omnivores with a preference for animals, followed by carnivores with a preference for fish and Cephalopoda (15 species; 34.9\%) and carnivores with a preference for fish and Decapoda (seven species; 16.3\%), whereas only Parablennius gattorugine $(2.3 \%)$ was characterized as an omnivore with a preference for plant material (Table 1).

For the investigation of diet overlap for the 43 species, 903 combinations were examined (Table S2), including species from all types of different habitats (i.e. pelagic, benthopelagic, reef-associated, and demersal; Table 1). Out of those combinations, 176 (19.5\%) were null, indicating no significant diet overlap, whereas in 15 more cases $S$-values were $<0.001$. Values exceeded the 0.6 threshold in only 33 cases (3.7\%), above which, the overlap is considered significant (Table 2; Table S2). Based on the results of Schoener's index, there was no diet overlap for any combination of 17 species (namely: Belone belone, Cepola macrophthalma, Chromis chromis, Conger conger, Coris julis, Gaidropsarus mediterraneus, L. suerii, Lophius budegassa, L. piscatorius, P. gattorugine, Phycis blennoides, S. umbra, Scomber colias, Symphodus tinca, T. mediterraneus, Trachurus trachurus and T. lastoviza), whereas 


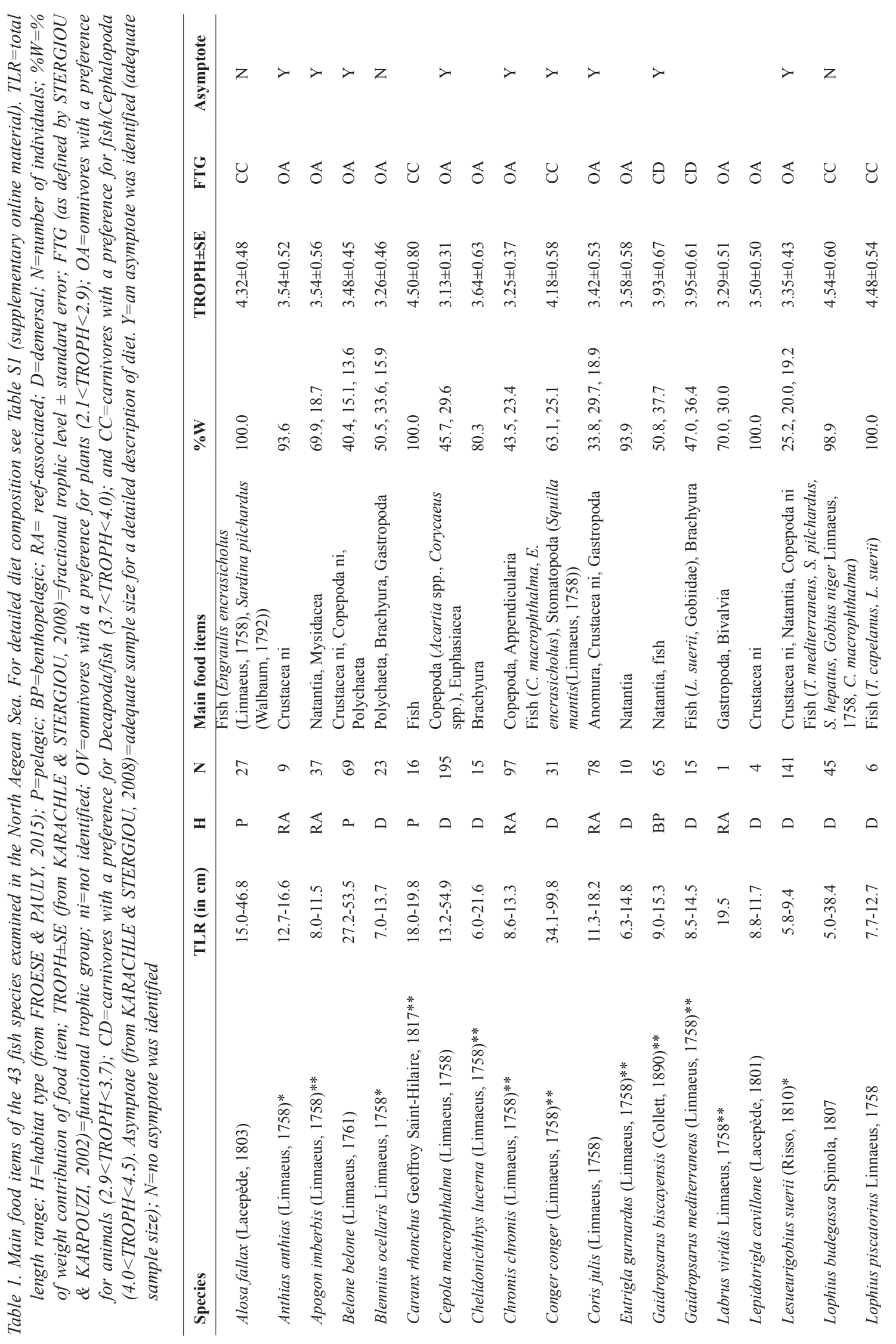




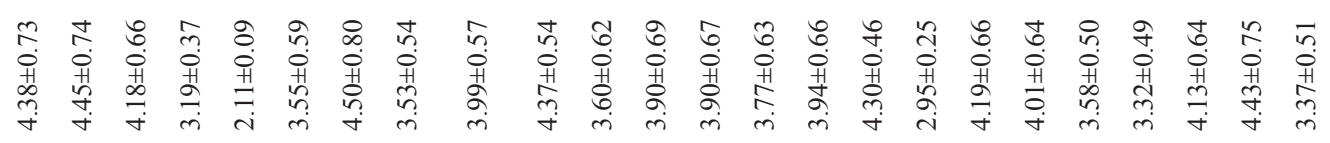

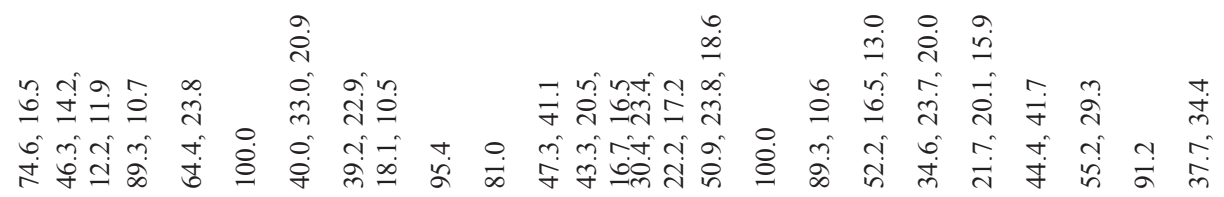

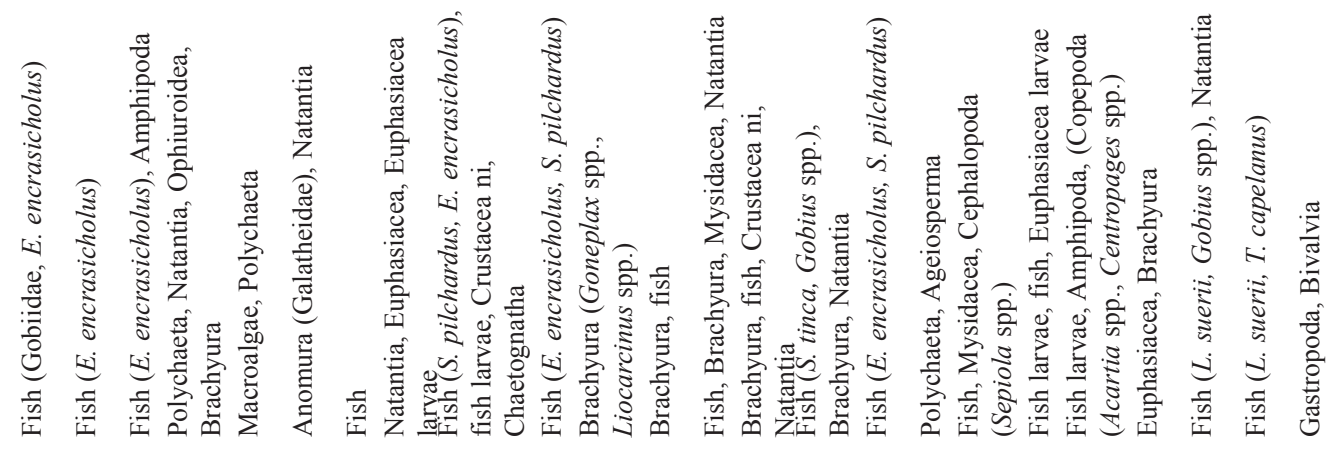
F $\bar{\lambda}$ ก

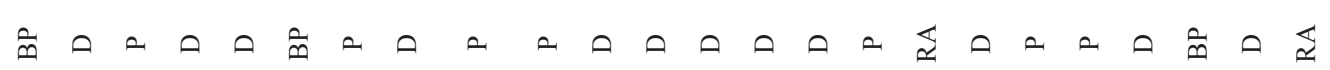

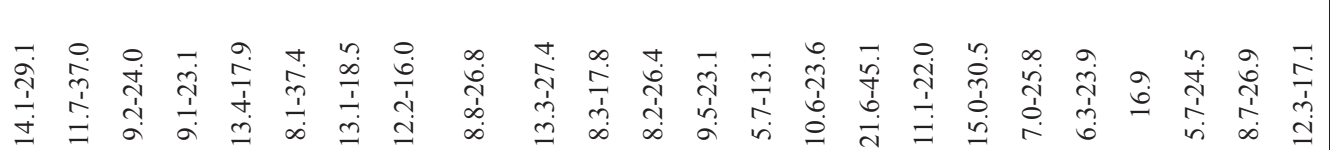




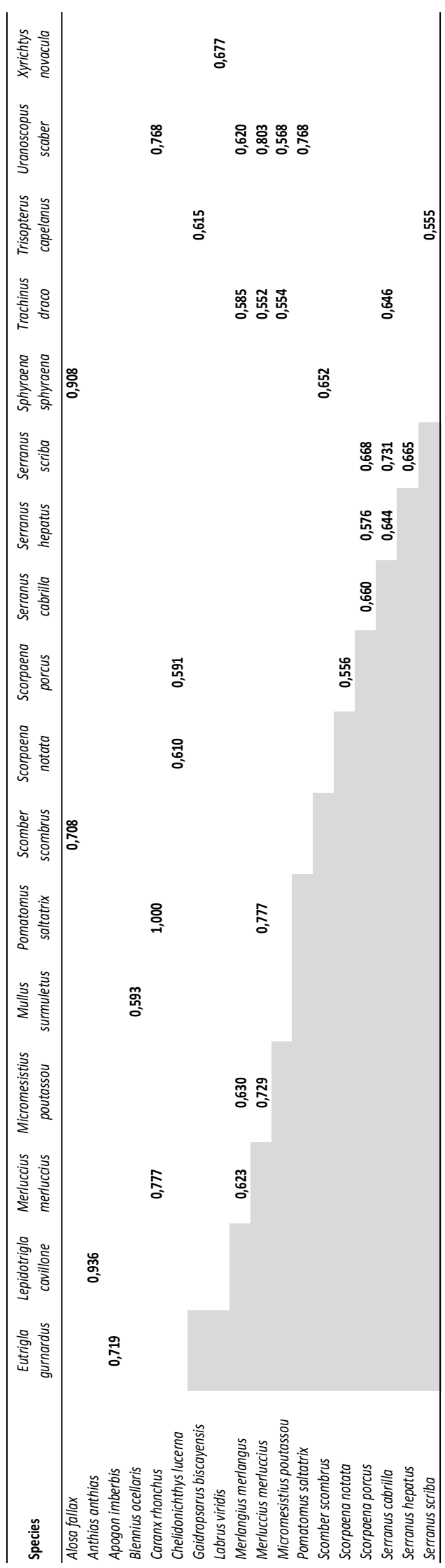

Table 2. Values of Schoener's index (SCHOENER, 1970) in pairs of combinations for fish species from the North Aegean Sea, where significant diet overlap (values $>0.6$ : ZARET \& RAND, 1971; WALLACE, 1981; WALLACE \& RAMSEY, 1983) was identified. Values of all pairs of combinations are given in Table S2 (supplementary online material).

the species with the highest number of overlaps with other fish was Merluccius merluccius, which showed diet overlap with another six species (i.e. C. rhonchus, M. merlangus, Micromesistius poutassou, P. saltatrix, Trachinus draco and Uranoscopus scaber). Finally, the value of Schoener's index was 1 only in one case, between $C$. rhonchus and $P$. saltatrix, indicating complete overlap of their diets.

\section{DISCUSSION}

This study presents the diet composition for 43 fish species from the N-NW Aegean Sea; for seven of those species, information on their feeding habits in the Mediterranean was lacking. A review of the literature has revealed that for Anthias anthias, Apogon imberbis, Blennius ocellaris, Lesueurigobius suerii and Sphyraena sphyraena, no stomach content analyses have been performed previously (also see STERGIOU \& KARPOUZI, 2002; KARACHLE \& STERGIOU, 2017); only general information of their food items exists (FROESE \& PAULY, 2015). The analyses performed in this study verify the general descriptions of the feeding habits of these species, with $A$. anthias, $A$. imberbis and $L$. suerii preying upon benthic Crustacea, B. ocellaris feeding on Polychaeta, Brachyura and Gastropoda, whereas $S$. sphyraena is a piscivorous fish. On the contrary, for Merlangius merlangus and Scomber scombrus, information on their diet composition and feeding habits in other areas of their distribution is available (e.g. M. merlangus: GORDON, 1977; DU BUIT, 1991; PEDERSEN, 1999, 2000; ICES, 2016; S. scombrus: CABRAL \& MURTA, 2002; OLASO et al., 2005; BACHILLER \& IRIGOIEN, 2015; ICES, 2016), indicating that they both feed primarily on other fish, a fact that is in accordance with the findings of this study. In addition, for 15 other species, the diet in the eastern part of the basin has not been studied to date (Table 1). The above mentioned 22 species fall within the data-deficient categories/species (STERGIOU \& 
KARPOUZI, 2002), as being important for a better understanding of marine ecosystems and for the implementation of integrated fisheries resource management models (e.g. STERGIOU \& POLUNIN, 2000; STERGIOU \& KARPOUZI, 2002, KARACHLE \& STERGIOU, 2008).

Studies on diet composition of fish shown that a number of stomachs ranging between 30 and 100 individuals, depending on species, could be sufficient enough for both description of diet and trophic level estimation (see KARACHLE \& STERGIOU, 2008 and references therein). In the present study, the sample size for 18 species was $<30$ (Table 1). Yet, for more than half of those 18 species (10 out of the 18 species) information on their diet composition in the East Mediterranean has not been studied before. In addition, for three more species out of the 18 aforementioned ones, the information presented here is the only existing one from the entire Mediterranean. Despite the fact that, in order to fully describe the diet of a species, an adequate sample is required, this cannot always be the case, especially for species that are rare or found in low abundances. Nevertheless, such information is still valuable especially in cases where there is a gap of knowledge, as for the majority of the under-sampled species presented here. In their review on feeding habits, STERGIOU \& KARPOUZI (2002) show that the vast majority of studied species in the Mediterranean are predators, whereas only five species were identified as omnivores with a preference for plants. Out of the 767 fish listed in FishBase (FROESE \& PAULY, 2015) as Mediterranean residents, only $35(4.56 \%)$ are omnivores with a preference for plants (trophic levels in the majority of cases estimated "based on size and trophic levels of closest relatives"). Those 35 species mainly include representatives of the families Blenniidae (12 species) and Mugilidae (seven species) (FROESE \& PAULY, 2015). Almost all of them are shallow water species with a depth distribution that only in a few cases exceed $50 \mathrm{~m}$ (FROESE \& PAULY, 2015). Samplings for this study were performed mainly at depths $>50 \mathrm{~m}$ and, consequently, omnivores with a preference for plants were under-represented. With the exception of Parablennius gattorugine, which was identified as omnivorous with a preference for plants, half of the species studied were omnivores with a preference for animal material, and the other half, carnivores preying on Cephalopoda, Crustacea and fish.

The diet of $P$. gattorugine in the Mediterranean has been studied previously by ZANDER \& BERG (1984) in the Banyuls area (West Mediterranean). According to the findings of these authors, the species is classified as an omnivore with a preference for animals (STERGIOU \& KARPOUZI, 2002). However, the sample size of ZANDER \& BERG (1984), as in the present study, was very small (i.e. four individuals). Therefore, the examination of a larger sample size, of individuals caught throughout the year is required to clarify the actual functional trophic group to which this species belongs. Additionally, in order to bridge the gap of knowledge regarding the functional trophic category of omnivores with a preference for plants, future studies should include the families of fish inhabiting shallow waters primarily, which have been poorly studied.

Interspecific dietary competition of Mediterranean fish has been studied previously, and various authors record, to varying degrees, an overlap in the feeding habits of fish species (e.g. MACPHERSON, 1979, 1981; HARMELIN-VIVIEN et al., 1989; COLLOCA et al., 1994; LABROPOULOU \& ELEFTHERIOU, 1997; CASTRIOTA et al., 2005, 2012; VALLS et al., 2011). Various factors involved in the avoidance of competition for food resources have been identified, such as morphology and size of predator (e.g. LABROPOULOU \& ELEFTHERIOU, 1997; COLLOCA et al., 1994), differentiating foraging tactics (e.g. MACPHERSON, 1979), prey size and species segregation (e.g. CASTRIOTA et al., 2005, 2012), and habitat separation (e.g. ZARET \& RAND, 1971; MACPHERSON, 1979, 1981; HARMELIN-VIVIEN et al., 1989; VALLS et al., 2011). Of the above-mentioned factors, habitat separation is considered as the most important factor reducing diet completion and overlap. In this study, the effect of habitat segregation on diet overlap is strongly reflected in the 176 cases of null overlap results (Table $\mathrm{S} 2$ ).

Schoener's index values revealed diet overlap in 33 cases (Table 2). In 15 out of the 33 
cases, the species occupied different habitat types, a fact that could result in reduced competition for food resources. However, in the remaining 18 out of the 33 cases of dietary overlap, the species shared the same habitat. Nevertheless, differences in morphology (e.g. Mullus surmuletus and B. ocellaris; S. scomber and $S$. sphyraena), or further habitat segregation where species occupy different microhabitats (e.g. Trachinus draco and Merluccius merluccius, and Uranoscopus scaber and M. merluccius: all species are benthic, with M. merluccius living close to the bottom, whereas T. draco and $U$. scaber generally rest on or in sand) could act as mitigating factors for competition.

Observations of diet overlap for Scorpaena notata and Scorpaena porcus was recorded in the North Aegean specimens examined. This is in accordance with the findings by HARMELINVIVIEN et al. (1989), who report overlap for the same food resources in scorpaenids inhabiting Posidonia oceanica meadows. The latter authors observe that this competition decreases during the night, when prey availability increases and there is a wider spectrum of potential food items, allowing co-existence of the two species. The observation of HARMELIN-VIVIEN et al. (1989) cannot be verified within the framework of this study, as samples originated from commercial fisheries and time of capture was not available.

High diet overlap was also identified among the three Serranus species (i.e. Serranus cabrilla, Serranus hepatus and Serranus scriba; all combinations $\mathrm{S}>0.60$ ). In their study LABROPOULOU \& ELEFTHERIOU (1997), when comparing the feeding habits of $S$. cabrilla and $S$. hepatus in the Cretan Sea, report no significant overlap, attributed to differences in morphological characteristics (i.e. mouth gape, the number of gill rakers). In the case of the North Aegean specimens, $S$. hepatus displayed notable differences in feeding-related morphological features with the other two species (KARACHLE \& STERGIOU 2010, 2011, 2012) but their diet still overlapped. Additionally, according to LABROPOULOU \& ELEFTHERIOU (1997), S. hepatus tends to consume small-sized prey with reduced motility. The S-values estimated here were based on food items that were not identified to species level and the size of prey items was not measured. If the above information was available, it is probable that the diet of $S$. hepatus would not actually overlap with that of the other two $S$. cabrilla and $S$. scriba, a hypothesis that needs further investigation.

On the other hand, S. cabrilla and S. scriba were similar morphologically (KARACHLE \& STERGIOU 2010, 2011, 2012), a fact that could support overlap in the food preferences of the species. However, the bathymetric distribution of the two species is different, with $S$. cabrilla showing a preference for deeper waters (FROESE \& PAULY, 2015). Hence, despite the fact that they prey on the same type of food and display morphological similarities, their spatial segregation may result in low interspecific competition or even no competition if food resources are not limited for their distribution (e.g. MACPHERSON, 1979, 1981; HARMELIN-VIVIEN et al., 1989; VALLS et al., 2011). The above assumption may apply to another set of species that showed high S-values, but occupied different habitats (e.g. between: A. anthias (reef-associated) and Lepidotrigla cavillone (demersal); Caranx rhonchus (benthopelagic), and M. merluccius and $U$. scaber (demersal); Pomatomus saltatrix (pelagic) and U. scaber (demersal) (habitat types from FROESE \& PAULY (2015)).

Finally, the complete overlap in the feeding habits of $C$. rhonchus and P. saltatrix (S value $=1$ ), could be attributed to the fact that very few individuals of both species were examined (16 and 6, respectively) and contained only bony fish remains. The piscivorous nature of both species was verified in this study, as previously shown in other parts of the world (e.g. C. rhonchus: SLEY et al., $(2007,2008)$; P. saltatrix: JUANES et al., (1993); DHIEB et al.,(2001)). However, in order to determine their feeding preferences, potential diet overlap and competition for food resources in the area properly, a larger sample size of both species needs to be examined and a finer grouping of prey items is required.

Summing up, this study provides information on the diet composition and overlap of fish species from the eastern Mediterranean, with 
emphasis on understudied species. Future studies on feeding habits should focus on species for which information on their feeding habits is limited, and especially on species inhabiting shallow habitats for which information is rather scarce, as well as commercial fish, in order to fill in knowledge gaps, as also proposed by KARACHLE \& STERGIOU (2017). This information is essential for the development of food-based models that would allow conservation and management of fisheries resources. In addition, the estimation of dietary overlap, using various indices alone, may not constitute solid proof of competition for food, as the latter could be a result of shortage in shared food resources (MACPHERSON, 1981; PIANKA, 1981), and hence other aspects of species biology and ecology should be considered.

\section{REFERENCES}

BACHILLER, E. \& X. IRIGOIEN. 2015. Trophodynamics and diet overlap of small pelagic fish species in the Bay of Biscay. Mar. Ecol. Progr. Ser., 534: 179-198.

BELL, J.D. \& M.L. HARMELIN-VIVIEN. 1983. Fish fauna of French Mediterranean Posidonia oceanica seagrass meadows. 2. Feeding habits. Tethys, 11: 1-14.

CABRAL, H.N. \& A.G. MURTA. 2002. The diet of blue whiting, hake, horse mackerel and mackerel off Portugal. J. Appl. Ichthyol., 18: 14-23.

CASTRIOTA, L., M.G. FINOIA \& F. ANDALORO. 2005. Trophic interactions between Xyrichtys novacula (Labridae) and juvenile Pagrus pagrus (Sparidae) in the Central Mediterranean Sea. e-J. Ichthyol., 2: 54-60.

CASTRIOTA, L., M. FALAUTANO, M.G. FINOIA, P. CONSOLI, C. PEDA, V. ESPOSITO, P. BATTAGLIA \& F. ANDALORO. 2012. Trophic relationships among scorpaeniform fishes associated with gas platforms. Helgoland Mar. Res., 66: 401-411.

COLLOCA, F., G.D. ARDIZZONE \& M.F. GRAVINA. 1994. Trophic ecology of gurnards (Pisces: Triglidae) in the Central Mediterranean Sea. Mar. Life, 4(2): 45-57.

DHIEB, K., M. GHORBEL \& A. BOUAIN. 2001. Regime alimentaire de Pomatomus saltatrix (Teleostei, Pomatomidae) dans le Golfe de Gabes, Tunisie. Rapp. Comm. int. Mer Médit., 36: 259.

DU BUIT, M.H. 1991. Alimentation du merlan, Merlangius merlangus (L., 1758), au large de l' Ecosse (Zones VIa et IVa). Cybium, 15(3): 211-220.
FROESE, R. \& D. PAULY. 2015. FishBase. In: R. Froese \& D. Pauly (Editors). www.fishbase. org (accessed 25 August 2015).

GORDON, J.D.M. 1977. The fish populations in inshore waters of the west coast of Scotland. The food and feeding of whiting (Merlangius merlangus L.). J. Fish. Biol., 11: 513529.

GOTSIS-SKRETAS, O. \& L. IGNATIADES. 2007. 1.2 The distribution of chlorophyll-a in the Aegean and Ionian Sea. In: C. Papaconstantinou, A. Zenetos, V. Vassilopoulou and G. Tserpes (Editors). State of Hellenic fisheries. Hellenic Center for Marine Research Publ., Athens, pp. 24-27.

ICES. 2016. Stomach Dataset. ICES-CIEM Stomach Data (1981-2010). Copenhagen. http:// ecosystemdata.ices.dk/stomachdata/index. aspx (accessed 30 January 2016).

JUANES, F., R.E. MARKS, K.A. MCKOWN \& D.O. CONOVER. 1993. Predation by age-0 bluefish on age- 0 anadromous fishes in the Hudson River estuary. Trans. Am. Fish. Soc., 122(3): 348-356.

HARMELIN-VIVIEN, M.L., R.A. KAIM-MALKA, M. LEDOYER \& S.S. JACOB-ABRAHAM. 1989. Food partitioning among scorpaenid fishes in Mediterranean seagrass beds. J. Fish. Biol., 34: 715-734.

HYSLOP, E.J. 1980. Stomach contents analysis - a review of methods and their application. J. Fish. Biol., 17: 411-429.

KARACHLE, P.K. \& K.I. STERGIOU. 2008. The effect of season and sex on trophic levels of marine fishes. J. Fish. Biol., 72: 1463-1487.

KARACHLE, P.K. \& K.I. STERGIOU. 2010. Gut length 
for several marine fishes: relationships with body length and trophic implications. Mar. Biodiv. Rec. 3, e106, 10 p.

KARACHLE, P.K. \& K.I. STERGIOU. 2011. Mouth allometry and feeding habits in fishes. Acta Ichthyol. Piscat., 41(4): 265-275.

KARACHLE, P.K. \& K.I. STERGIOU. 2012. Morphometrics and Allometry in Fishes. In: C. Wahl (editor). Morphometrics. InTech, pp. 65-86. Available from: http://www.intechopen.com/articles/show/title/morphometricsand-allometry-in-fishes

KARACHLE, P.K. \& K.I. STERGIOU. 2014. Feeding and ecomorphology of three clupeoids in the North Aegean Sea. Mediter. Mar. Sci., 15(1): 9-26.

KARACHLE, P.K. \& K.I. STERGIOU. 2017. An update on the feeding habits of fish in the Mediterranean Sea (2002-2015). Mediter. Mar. Sci., 18(1): 43-52.

LABROPOULOU, M. \& A. ELEFTHERIOU. 1997. The foraging ecology of two pairs of congeneric demersal fish species: importance of morphological characteristics in prey selection. J. Fish. Biol., 50(2): 324-340.

LINK, J.S. \& F.P. ALMEIDA. 2000. An overview and history of the food web dynamics program of the Northeast Fisheries Science Center, Woods Hole, Massachusetts. NOAA Tech Memo NMFS-NE-159, 60 pp.

MACPHERSON, E. 1979. Ecological overlap between macrourids in the Western Mediterranean Sea. Mar. Biol., 53(2): 149-159.

MACPHERSON, E. 1981. Resource partitioning in a Mediterranean demersal fish community. Mar. Ecol. Progr. Ser., 4: 183-193.

MONCHEVA, S., O. GOTSIS-SKRETAS, K. PAGOU \& A. KRASTEVA. 2001. Phytoplankton blooms in Black Sea and Mediterranean coastal ecosystems subjected to anthropogenic eutrophication: similarities and differences. Estuar. Coast. Shelf Sci., 53: 281-295.

MORATO, T., E. SOLA, M.P. GROS \& G. MENEZES. 2003. Diets of thornback ray (Raja clavata) and tope shark (Galeorhinus galeus) in the bottom longline fishery of the Azores, northeastern Atlantic. Fish. Bull., 101: 590-602.

NIKOLIOUDAKIS, N., S. ISARI \& S. SOMARAKIS.
2014. Trophodynamics of anchovy in a nonupwelling system: direct comparison with sardine. Mar. Ecol. Progr. Ser., 500: 215229.

NIKOLIOUDAKIS, N., S. ISARI, P. PITTA \& S. SOMARAKIS. 2012. Diet of sardine Sardina pilchardus: an "end-to-end" field study. Mar. Ecol. Progr. Ser., 453: 173-188.

NIKOLIOUDAKIS, N., I. PALOMERA, A. MACHIAS \& S. SOMARAKIS. 2011. Diel feeding intensity and daily ration of the sardine Sardina pilchardus. Mar. Ecol. Progr. Ser., 437: 215228.

OLASO, I., J.L. GUTIÉRREZ, B. VILLAMOR, P. CARRERA, L. VALDÉS \& P. ABAUNZA. 2005. Seasonal changes in the north-eastern Atlantic mackerel diet (Scomber scombrus) in the north of Spain (ICES Division VIIIc). J. Mar. Biol. Assoc. U.K., 85(2): 415-418.

PAGOU, K. 2005. Eutrophication in the Hellenic coastal areas. In: E. Papathanassiou and A. Zenetos (Editors). State of the Hellenic marine environment. Hellenic Center for Marine Research Publ., Athens, pp. 311-317. PAPACONSTANTINOU, C. 2005. The Hellenic fisheries. In: E. Papathanassiou and A. Zenetos (Editors). State of the Hellenic marine environment. Hellenic Center for Marine Research Publ., Athens, pp. 272-79.

PAULY, D. 2000. Predator-prey ratios in fishes. In: R. Froese and D. Pauly (Editors). FishBase 2000: Concepts, Design and Data Sources. ICLARM, Manila, p. 201.

PAULY, D., R. FROESE, P. SA-A, M.L. PALOMARES, V. CHRISTENSEN \& J. RIUS. 2000. TrophLab Manual. ICLARM, Manila, 3 pp.

PEDERSEN, J. 1999. Diet comparison between pelagic and demersal whiting in the North Sea. J. Fish. Biol., 55: 1096-1113.

PEDERSEN, J. 2000. Food consumption and daily feeding periodicity: comparison between pelagic and demersal whiting in the North Sea. J. Fish. Biol., 57: 402-416.

PIANKA, E.R. 1981. Competition and Niche Theory. In: R.M. May (Editor). Theoretical Ecology, 2nd edn. Blackwell, pp. 167-196.

SCHARF, F.S., F. JUANES \& R.A. ROUNTREE. 2000. Predator size - prey size relationships of 
marine fish predators: Interspecific variation and effects of ontogeny and body size on trophic niche breadth. Mar. Ecol. Progr. Ser., 208: 229-248.

SCHOENER, T.W. 1969. Nonsynchronous spatial overlap of lizards in patchy habitats. Ecology, 51(3): 408-418.

SLEY, A., O. JARBOUI \& A. BOUAIN. 2007. Données préliminaires sur le régime alimentaire de Caranx rhonchus (Osteichtyens, Carangidae) dans le Golfe de Gabés (Tunisie). Rapp. Comm. int. Mer Médit., 38: 601.

SLEY, A., O. JARBOUI, M. GHORBEL \& A. BOUAIN. 2008. Diet composition and food habits of Caranx rhonchus (Carangidae) from the Gulf of Gabés (central Mediterranean). J. Mar. Biol. Assoc. U.K., 88(4): 831-836.

STERGIOU, K.I. \& V.S. KARPOUZI. 2002. Feeding habits and trophic levels of Mediterranean fish. Rev. Fish Biol. Fish., 11: 217-254.

STERGIOU, K.I. \& N. POLUNIN. 2000. Executive summary. In: F. Briand (Editor). Fishing Down the Mediterranean Food Webs? CIESM Workshop Series, Vol 12, pp. 7-15.

STERGIOU, K.I., D.C. BOBORI, F.G. EKMEKÇI, M. GÖKOĞLU, P.K. KARACHLE, G. MINOS, Y. ÖZVAROL, I. SALVARINA, A.S. TARKAN \& L. VILIZZI. 2014. New Fisheries-related data from the Mediterranean Sea (April, 2014).
Mediter. Mar. Sci., 15(1): 213-224.

TSAGARAKIS, K., M. COLL, M. GIANNOULAKI, S. SOMARAKIS, C. PAPACONSTANTINOU \& A. MACHIAS. 2010. Food-web traits of the North Aegean Sea ecosystem (Eastern Mediterranean) and comparison with other Mediterranean ecosystems. Estuar. Coast. Shelf Sci., 88: 233-248.

VALLS, M., A. QUETGLAS, F. ORDINES \& J. MORANTA. 2011. Feeding ecology of demersal elasmobranchs from the shelf and slope off the Balearic Sea (western Mediterranean). Sci. Mar., 75(4): 633-639.

WALLACE, R.K. 1981. An assessment of diet-overlap indexes. Trans. Am. Fish. Soc., 110(1): 72-76.

WALLACE, R.K. \& J.S. RAMSEY. 1983. Reliability in measuring diet overlap. Can. J. Fish. Aquat. Sci., 40: 347-351.

ZANDER, C.D. \& J. BERG. 1984. Feeding ecology of littoral gobiid and blennioid fishes of the Banyuls area (Mediterranean Sea). II. Prey selection and size preference. Vie et Milieu, 34(2-3): 149-158.

ZARET, T.M. \& A.S. RAND. 1971. Competition in tropical stream fishes: support for the competitive exclusion principle. Ecology, 52(2): 336-342. 


\title{
Sastav prehrane i preklapanja prehrambenih navika kod 43 vrste riba u sjevernom Egejskom moru, Grčka
}

\author{
Paraskevi K. KARACHLE \\ Kontakt e-adresa: pkarachle@hcmr.gr
}

\section{SAŽETAK}

Ova studija bavi se sastavom prehrane 43 vrste koje spadaju u neke od najbrojnijih vrsta riba u sjevernom Egejskom moru, Grčka. Prema analizi prehrane i razine frakcijskih trofičkih razina o kojima se prije izvještavalo u literaturi, 20 vrsta od ukupnog broja istraživanih su svežderi koji preferiraju životinje, a druga polovica su mesojedi (15 od kojih preferira ribe i glavonošce, a sedam ih preferira ribe i deseteronošce) dok je Parablennius gattorugine jedini zabilježeni svežder koji preferira biljke. Naposljetku, prema rezultatima Schoenerova indeksa, preklapanja prehrambenih navika zabilježena su kod malog broja slučajeva (33 od 903 ispitivana para). Ipak, konkurencija među vrstama kod kojih se prehrambene navike preklapaju može se umanjiti bilo morfološkim diferencijacijama bilo segregacijom staništa.

Ključne riječi: prehrambene navike, preklapanje u prehani, Schoenerov indeks, Egejsko more, istočno Sredozemlje 